\title{
Nordic Journal of
}

Linguistics

Volume 16

Number 2

1993

\section{SCANDINAVIAN UNIVERSITY PRESS}

Oslo-Copenhagen - Stockholm - Boston 


\section{Contents}

Vol. 16, No. 21993

Special issue on NEUROLINGUISTICS

Jussi Niemi, Matti Laine \& Jürgen Tesak: Introducing the NJL Special Issue on Neurolinguistics 81

Jussi Niemi, Matti Laine \& Jürgen Tesak: Brains and

Languages: A Survey of Neurolinguistics 83

Inger Moen: Phonological Deviations in Norwegian

Conduction Aphasia: Testing a Model of Non-Linear Phonology 99

Gary Libben: A Case of Obligatory Access to

Morphological Constituents 111

Pirkko Kukkonen: On Paragrammatism in Finnish 123

Elisabeth Ahlsén: On Agrammatism and Telegram Style:

An Exemplifying Discussion of Swedish Data 137

Hans-Jürgen Eikmeyer \& Ulrich Schade: The Role of

Computer Simulation in Neurolinguistics 153

Reviews 171

Publications Received 198 


\title{
Special Issue on
}

\section{NEUROLINGUISTICS}

\author{
Guest-edited by
}

Jussi Niemi, Matti Laine \& Jürgen Tesak 


\section{Contents}

\section{Vol. 16, No. 21993}

\section{Special issue on NEUROLINGUISTICS}

Jussi Niemi, Matti Laine \& Jürgen Tesak: Introducing the $N J L$ Special Issue on Neurolinguistics

Jussi Niemi, Matti Laine \& Jürgen Tesak: Brains and Languages: A Survey of Neurolinguistics.

Inger Moen: Phonological Deviations in Norwegian Conduction Aphasia: Testing a Model of Non-Linear Phonology ................................

Gary Libben: A Case of Obligatory Access to Morphological Constituents

Pirkko Kukkonen: On Paragrammatism in Finnish

Elisabeth Ahlsén: On Agrammatism and Telegram Style: An Exemplifying Discussion of Swedish Data...

Hans-Jürgen Eikmeyer \& Ulrich Schade: The Role of Computer Simulation in Neurolinguistics

\section{Reviews}

Ilse Lehiste: Review of Kristján Árnason, The Rhythms of Dróttkvaett and other Old Icelandic Metres.............................................. 171

Kjell Johan Sabo: Review of Ekkehard König, The Meaning of Focus Particles. A Comparative Perspective .................................... 179

Helge Lødrup: Review of Jerrold M. Sadock, Autolexical Syntax: A Theory of Parallel Grammatical Representations....

Kjell Ivar Vannebo: Review of Niels Davidsen-Nielsen, Tense and Mood in English. A Comparison with Danish

Publications Received 